TITLE:

\title{
AN AUTORADIOGRAPHIC STUDY ON THE TERMINAL DISTRIBUTION OF CEREBELLOTHALAMIC FIBERS IN THE CAT( Abstract_要旨 )
}

\section{$\operatorname{AUTHOR}(\mathrm{S}):$}

Sugimoto, Tetsuo

\section{CITATION:}

Sugimoto, Tetsuo. AN AUTORADIOGRAPHIC STUDY ON THE TERMINAL DISTRIBUTION OF CEREBELLOTHALAMIC FIBERS IN THE CAT. 京都大学, 1981, 医学博士

ISSUE DATE:

1981-03-23

URL:

http://hdl.handle.net/2433/222874

RIGHT: 


\section{【140】}

氏 名
学位の種類
学位記番号
学位授与の日付
学位授与の要件
研 究 科・専 攻
学位論文題目

禁本哲去

医学 博 士

医 博 第 573 号

昭 和 56 年 3 月 23 日

学位規則第 5 条第 1 項該 当

医学研究科生理系専攻

AN AUTORADIOGRAPHIC STUDY ON THE TERMINAL DISTRIBUTION OF CEREBELLOTHALAMIC FIBERS IN THE CAT

（ネコ小脳視床線維終末分布のオートラジオグラフィー法による研究）

論文調査委員表查) 荒木辰之助教授半田 肇教授水野昇

\section{論 文 内容の要旨}

小脳視床線維は小脳の上行性連絡系に括いて重要な機能を有するものと考兄られるが，その終未分布に 関する系統的で精細な形態学的研究は少ない。また，これまでの研究所見は主として変性法に基づくもの であった。本研究では，ネコの小脳核の㧍のおのに放射性アミノ酸を注入し，その順行性軸索輸送を利用 して，小脳視床線維の視床内終止部位をオートラジオグラフィーによって決定した。

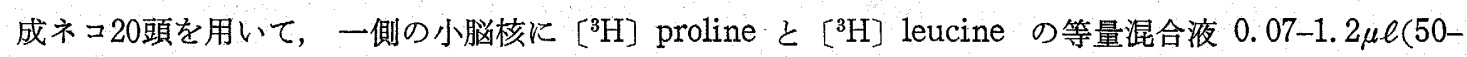
$100 \mu \mathrm{Ci} / \mu \ell)$ を脳定位法により注入した。これらのネコをさらに $7-23$ 日間生存させたのち, 経心臓灌流 法により固定して脳を採取した。小脳・視床を含を脳幹の $35 \mu \mathrm{m}$ 連続前頭断水結切片を作製して光顕的 オートラジオグラフィーを実施した。これらの切片をさらにクレシルバイオレットを用いて対比細胞染色 したのち，終末銀粒子の分布と細胞構筑を明視野㧍よび暗視野顕徽鏡により観察した。

一側の小脳核全体に放射性つミノ酸を注入すると，反対側視床に执いて，主として腹側核 (VA・VL・ $\mathrm{VM})$ と㖪板内核 $(\mathrm{Pc} \cdot \mathrm{CL})$, 内側中心核 $(\mathrm{NCM})$ 飞終末銀粒子が出現し，その他，正中中心核とその付 近 $(\mathrm{CM} \cdot \mathrm{Pf} \cdot \mathrm{Spf})$, 外側滕状体腹側核 $(\mathrm{GLv})$, 視床枕 $(\mathrm{Pul})$, 背内側核 $(\mathrm{MD})$, 視床網様核 $(R)$, 腹側 視床 $(\mathrm{ZI})$ にも少数の標識銀粒子をみとめた。注入側の視床では, 反対側 $\mathrm{VA} \cdot \mathrm{VL} \cdot \mathrm{VM}$ の標識部位と対 称の領域に軽度の標識をるた。戦脳内側核注入例では反対側 VL 腹外側部の小領域と, VM 背外側部から それと隣接するVL 腹内側部におよぶ領域の 2 ケ所に終末銀粒子が集積した。このうち前者の VL 領域の 尾側レベルではVPL 背側部に接する小領域が標識された。䯣板内核・CM・ZI にも軽度の標識がみられ た。小脳内側核から視床に投射する線維はほとんど小脳内側核の尾側半分から起始することが推定でき た。小腷外側核注入例ではVA V V $の$ 内側部に多数の終末銀粒子が出現した。また，䯣板内核・NCM ・ $\mathrm{CM} \cdot \mathrm{LP} \cdot \mathrm{Pul} \cdot \mathrm{MD} \cdot \mathrm{VM}$ には少数の標識銀粒子がみられた。VA $\cdot \mathrm{VL}$ 内の投射部位と小脳外側核との 間には背腹方向の局在投射関係があった。すなから小脳外側核の腹側部からはVA と VL の背内側部に 終末投射がみられ，また一方，小脳外側核の背側部からはVL の腹内側部に終末投射がみられた。小这 
後中位核注入例では VL の中央部が主として標識されたが, VA・CM・Spf $\cdot \mathrm{GLV} ・ \mathrm{ZI}$ にも少数の標識 終末がみられた。後中位核から VLへの投射には背腹方向の部位局在性がみられた。小脳前中位核注入 例ではVL の外側部に多数の終末銀粒子が出現した。VL の尾側半レベルではVPL に隣接するVL 領 域が標識されたが, VPL 内に標識が拉よんでいる例もめった。ほかに CM・CL が軽度標識された。

以上，本研究では，神経路の順行性追跡法のうち，現在最も鋭敏と考えられているオートラジオグラフ ィ一法を用いた結果，個々の小脳核から起始する小膗視床線維の各視床核への終末分布を明確に把握しえ た。とくに視床腹側核群 (VA・VL・VM) への終末分布に関しては，核群全体としてその内外方向に， 小脳内側核・外側核・後中位核・前中位核の順にこれらの小脳核からの投射部位が局在配列すること，さ らにVA・VL 内では小脑外側核と後中位核からの線維の終末分布に背腹方向の局在配列関係があること を見出した。むた VL・VM 領域には小脳外側核と内側核の両者から共通に投射を受ける小領域が存在す ることが明らかになった。

\section{論文審查の結果の要旨}

小脳疾患の病態生理を解明するためには小脳の神経線維連絡関係の精細な知見が必要である。小脳の遠 心性神経線維連絡系のなかで，小脳視床線維は小脑から終脳への連絡系の基幹を形成する重要な線維群で あるが，その終末分布に関してはこれまで信頼できる知見に乏しかった。これは，この線維群に関するこ れまでの形態学的研究が主として変性法によっており，方法上の欠点が大きかったためである。本研究で は，放射性アミノ酸の順行性軸索輸送を利用するオートラジオグラフィーを用いることにより，变性法に ともなっていた方法上の欠点が克服されている。その結果，本研究では，それぞれの小脳核から起始する 小脳視床線維の終末分布が明確にされ，これまでの知見の多くが修正された。とくに小脳核群と視床腹側 核群との間にみられる部位局在配列関係を正確に把握し得た点は重要である。以上のように，本研究は小 脳の神経線維連絡に関して多くの新知見をもたらし，小脳機能や小脳症状の発現機構の解明に寄与すると ころが大きい。

したがって，本論文は医学博士の学位論文として価値あるものと認める。 